UDC 94(477)"1941/1944":792.03(477)

\author{
Ilnytskyi Vasyl \\ PhD hab. (History), Associate Professor, \\ Head of the Ukraine's History Department \\ of Drohobych Ivan Franko State \\ Pedagogical University \\ ORCID 0000-0002-4969-052X \\ vilnickiy@gmail.com \\ Haliv Mykola \\ PhD (Education), Associate Professor \\ of the Department of History of Ukraine \\ of Drohobych Ivan Franko State \\ Pedagogical University \\ ORCID 0000-0001-7068-3124 \\ halivm@yahoo.com
}

\title{
THE ACTIVITY OF THE UKRAINIAN THEATRE IN PEREMYSHL DURING THE NAZI OCCUPATION (1941-1944) ${ }^{1}$
}

\begin{abstract}
The purpose of the research is to discover the organizational-administrative and creative-artistic aspects of the activity of the Ukrainian Theatre in Peremyshl in the years of the Hitlerite's occupation of the town. The research methodology is based on the principles of historicism, system-formation, scientific character, verification, the author's objectivity, moderated narrative constructivism, and the use of general scientific (analysis, synthesis, generalization) and specially-historical (historical-genetic, historical-typological, historical-systemic, etc.) methods. The scientific novelty of the article consists in the argumentation of the fact, that, for the first time, in the historiography of the Ukrainian theatrical art on the basis of the previously unknown archival documents, the genesis, organizational development, repertoire, administration, and actors' staff of the Ukrainian Theatre in Peremyshl in the years of its occupation by the Hitlerites are clarified. Conclusions. Summing up, the fact is that the historical genesis of the Ukrainian Theatre in Peremyshl was connected with the activity of "Lesia Ukrainka theatrical society" (1925-1939) and the Soviet State regional drama theatre (1940-1941). The history of the Ukrainian Theatre in Peremyshl can be divided into three stages: 1) the stage of the formation of the theatre in a form of the Theatrical circle and Drama section of UAC (1942 - first half of 1943), 2) the stage of the theatre's reorganization into a professional establishment (August-October, 1943), 3) the stage of the theatre's vigorous activity on professional bases (November of $1943-$ July of 1944). The Ukrainian Theatre's artistic experience was manifested by several dozens of first-night performances and almost one hundred of other productions in Peremyshl and the neighboring villages and towns.
\end{abstract}

Key words: theatre; Peremyshl; the Nazi occupation; theatrical art.

Ільницький Василь Іванович, доктор історичних наук, доцент, завідувач кафедри історії України Дрогобицького державного педагогічного університету імені Івана Франка; Галів Микола Дмитрович, кандидат педагогічних наук, доцент кафредри історії України Дрогобицького державного педагогічного університету імені Івана Франка

Діяльність Українського театру у Перемишлі в роки нацистської окупації (1941 - 1944)

Мета дослідження - розкрити організаційно-адміністративні та творчо-мистецькі аспекти діяльності Українського театру в Перемишлі у роки гітлерівської окупації міста. Методологія дослідження спирається на принципах історизму, системності, науковості, верифікації, авторської об'єктивності, поміркованого наративного конструктивізму, а також на використання загальнонаукових (аналіз, синтез, узагальнення) та спеціально-історичних (історико-генетичний, історико-типологічний, історикосистемний) методів. Наукова новизна полягає у тому, що вперше в історіографії українського театрального мистецтва на основі невідомих раніше архівних документів з'ясовано виникнення, організаційну розбудову, репертуар, управлінський та акторський склад, мистецьку діяльність Українського театру в Перемишлі у роки гітлерівської окупації. Висновки. Історична ґенеза Українського театру в Перемишлі пов'язана з діяльністю українського "Драматичного товариства ім. Лесі Українки" (1925-1939) та радянського Державного обласного драматичного театру (1940-1941). Історію Українського театру в Перемишлі можна поділити на три етапи: 1) етап становлення театру у формі Драматичного гуртка і Драматичної секції УдК (1942 - перша половина 1943 р.), 2) етап реорганізації театру на професійну установу (серпень - жовтень 1943 р.), 3) етап активної мистецької діяльності театру на професійних засадах (листопад 1943 - липень 1944 рр.). Мистецький доробок Українського театру позначився кількома десятками прем'єр і майже сотнею вистав у Перемишлі та сусідні містах і селах.

Ключові слова: театр; Перемишль; нацистська окупація; театральне мистецтво.

Ильницкий Василий Иванович, доктор исторических наук, доцент, заведующий кафредрой истории Украины Дрогобычского государственного педагогического университета имени Ивана Франко; Галив Николай Дмитриевич, кандидат педагогических наук, доцент, доцент кафедры истории Украины Дрогобычского государственного педагогического университета имени Ивана Франко

Деятельность Украинского театра в Перемышле в годы нацистской оккупации (1941-1944)

Цель исследования - раскрыть организационно-административные и творчески-художественные аспекты деятельности Украинского театра в Перемышле в годы гитлеровской оккупации города. Методология исследования опирается на принципах историзма, системности, научности, верификации, авторской объективности, умеренного нарративного конструктивизма, а также на использование общенаучных (анализ, синтез, обобщение) и специально-исторических (историкогенетический, историко-типологический, историко-системный) методов. Научная новизна заключается в том, что впервые в историографии украинского театрального искусства на основе неизвестных ранее архивных документах выяснено возникновения, организационную перестройку, репертуар, управленческий и актерский состав, художественную деятельность Украинского театра в Перемышле в годы гитлеровской оккупации. Выводы. Исторический генезис Украинского театра в Перемышле связан с деятельностью украинского "Драматического общества им. Леси Украинки" (1925-1939) и советского Государственного областного драматического театра (1940-1941). Историю Украинского театра в Перемышле можно разделить на три этапа: 1) этап становления театра в форме драматического кружка и Драматической секции УдК (1942 - первая половина 1943), 2) этап реорганизации театра на профессиональное учреждение (август - октябрь 1943) 3) этап активной творческой деятельности

(C) Ilnytskyi V., 2019

(C) Haliv M., 2019 
театра на профессиональной основе (ноябрь 1943 - июль 1944). Художественные достижения Украинского театра проявились в нескольких десятках премьер и более сотни спектаклей в Перемышле и соседние городах и селах.

ключевые слова: театр; Перемышль; нацистская оккупация; театральное искусство.

Formulation of the problem. At the present stage of development of scientific researches into the Ukrainian theatre's history it is the studying of the activity of independent centres of stage art in small local environments that gains urgency nowadays. Studying of the history of "small theatres" is a necessary condition and a sine qua non for a larger scale investigation of the history of theatrical life of each locality and every region of the country. The investigations of this kind at the country study and micro-historical levels give a chance to find out the details of a historical process and - in a more thorough and concentrated way - to consider transformation processes in artistic life. Such studies provide researches a considerable scope of interesting examples and the facts, the use of which can enrich any macro-historical synthesis. All the aforementioned approaches have grounded this article's attention to a small Ukrainian Theatre, which actively worked during the years of the Nazi occupation in Peremyshl, the old town which played a significant role in the cultural life in the Ukrainian lands in the XIX - fiest half of the XX century.

The analysis of researches and publications. For a rather long time the issue of theatrical life in the occupied territory remained beyond an appropriate attention of researchers. L. Waniuga,S and O. Demidko's articles [3; 6] are a study of theatrical activity in separate occupied towns. The development of theatre life in Peremyshl during the years of the Nazi occupation is fragmentarily elucidated in V. Haidabura's [4; 5], O.Popovych [12], S. Zabrovarnyi [7] research. His former collaborators M. Prasitskyi [13], O. Urbanskyi [14] a. o.) and followers (M. Pylyp-Andrushkiv [11], a. o.) also paid some scientific attention to the study of the Ukrainian Theatre. However, their works are mostly constructed upon memoirs, although they also contain references to certain source materials. The document of an unknown author, entitled "The History of the Theatre in Peremyshl", which has been discovered in the Central state archive of public associations of Ukraine, is of uncommon value for the revelation of the theme under consideration [15, 7-8].

The purpose of the research is to discover the organizational-administrative and creative-artistic aspects of the activity of the Ukrainian Theatre in Peremyshl in the years of the Hitlerite's occupation of the town.

The research methodology is based on the principles of historicism, system-formation, scientific character, verification, the author's objectivity, moderated narrative constructivism, and the use of general scientific (analysis, synthesis, generalization) and specially-historical (historical-genetic, historical-typological, historical-systemic, etc.) methods.

The statement of the basic materials. In the year of the II World War the public life of Peremyshl, an ancient Galician town stretched along the both banks of the Sian river, was affected by the domination of two totalitarian regimes, namely the Soviet and the Nazi-German. On September $28^{\text {th }}$, 1939, the right-bank (eastern) part of the town was occupied by the Red army units. At the same time, the left-bank (western) part of Peremyshl appeared under German occupation that was fixed by the Soviet-German treaty of friendship and borders on September $29^{\text {th }}$, 1939. Shortly afterwards the town became the district centre within Drohobych region of the Ukr.SSR. In the course of the Sovietization of public life in the attached to the Soviet Union West Ukrainian lands the new power paid a solid attention to the organizations of theatres. According to the Decree of the Council of the People's Commissars of the Ukr.SSR of December 19 ${ }^{\text {th }}$, 1939, in Drohobych region the State Regional Ukrainian Drama Theatre was founded (Drohobych) [9, 70]. A bit later the theatres were founded also in Boryslav and Stryi [1; 8], and than in Peremyshl. As a matter of fact, the researcher from Peremyshl O. Popovych connects the Theatre in Peremyshl with State Regional Ukrainian Drama Theatre in Boryslav. Furthurmore, she considers this particular theatre "a unique example of the Ukrainian professional dramatic activity in the history of the town" [12, 8].

As researcher S. Zabrovarnyi informs, together with educators and cultural workers, professional actors from the theatres of Zhytomyr, Kharkiv, and Chernihiv arrived in Peremyshl. It was of them that the State Drama Theatre had been created which already in November of 1940 began its activity with the premiere of "The Sorochyntsi Fair". The performances took place in an auditorium in a scenic hall of Peremyshl Castle. The theatre personnel were 40 persons, and Ivan Moiseyevych Neniuk was its head and director. Of the older generation of actors the following staff acted: F. B. Denysenko, K. M. Istomin, V. S. Chornyi, and K.Bezruchko; of the younger generation the following actors performed: G. A. Zaslavets, O. A. Shybko, K.L.Marinchak, M. M.Piskun, and others. The theatre's following performances were "The Marriage Engagement in Honcharivka" and B. Lavriniov's "Rozlom" ("The Break-up") [7]. It should be noticed, that during the election to the local councils in December of 1940 the actress of this Theatre, namely Olha Shybko worked on her way up to the deputy of Peremyshl town council [2].

After the beginning of the German-Soviet war on June $22^{\text {nd }}, 1941$, Peremyshl was occupied by German troops. The occupational power attached Peremyshl land to Kraków district of the General Province, having cut it off from Galician district with its centre in Lviv [10, 80]. As is known, multifarious Ukrainian public organizations, in particular, cultural establishments, operated under the surveillance of the Ukrainian Central Committee (UCC) headed by V. Kubijovych. Its organizational cells in counties were the Ukrainian aiding committees (UAC), which had their representatives in certain towns. By the middle of 1941 the UACs existed 
in Yaroslav, whereas in the left-bank Peremyshl only it was rerepresented only by its delegate body which was headed by Father Yulian Tatomyr. Nevertheless, in November of 1941 a UAC was founded in Peremyshl. Yevhen Zyblikevych was confirmed Chairman of Peremyshls UAC, which was situated in the "Narodnyu Dim" ("People's House") [7].

It was under the aegis of the UAC in Peremyshl that an amateur theatre group was created [15, 7]. As M. Prasitskyi, one of its most active members, recollected after the II World War, the group (which - in due course - evolved into the Ukrainian Theatre) was created on a basis of "Lesia Ukrainka theatrical society" that functioned in Peremyshl in 1925 - 1939 [13, 337]. Actually, he had certain reasons for such a statement, as the Ukrainian theatrical life in Peremyshl was reanimated under the conditions of German occupation exactly thanks to the efforts of "Lesia Ukrainka theatrical society's" former active participants, among them - Y. Kostiuk, Y. Andrukhovych, O. Chubynskyi, and M. Prasitskyi, to name a few.

However, it is impossible to ignore a certain contribution of the workers of the Soviet state theatre in Peremyshl $(1940$ - 1941) into the formation of the Ukrainian Theatre. In the spring of 1942, after the border between Galician and Krakow districts had been opened, six professional actors of the former Soviet State Theatre joined the theatre group by the UAC in Peremyshl [15, 7]. From Maria Pylyp-Andrushkiv's memoirs we know the names of several of them: Lyudmyla Ostroumova, Anna Kalnyts'ka, Hryhoriy Zaslavets, and Tetiana Bolkun [11, 308].

Yulian Kostiuk became the director of the theatre group. The group's material and financial condition was poor, as the property of the former Soviet Theatre was stolen at the initial stage of the German-Soviet war. So, it had no uniform suits and scenery [15, 7]. However, after the arrival of the six aforementioned actors and actresses, the group began to operate. M. Prasitskyi also admits this fact, calling them "professionals from the Bolshevist Theatre" [13, 338]. The play "Poshylysia v durni" ("They were made fools") was the first performance which the group presented to the local spectators on March $7^{\text {th }}, 1942$. The professional company also prepared the performances "Char odnostroiu" ("The magic of the uniform") and "Zhyvi pokiinyky" ("The Live Deceased"), with which it toured a number of small towns and villages of Peremyshl region. Actors Y. Kostiuk, H. Zaslavets, and M. Prasitskyi were producers. In July of the same year, the group was reorganized into a Drama section of the UAC section in Peremyshl. Oleksander Smishkevych became its director, he also created an amateur orchestra and conducted it. Unfortunately, except O. Smishkevych, nobody took care of the section, which did not even have its constant shelter where it could rehearse [15, 7].

In the end of October, 1942 O. Smishkevych had to leave Peremyshl for official reasons and the orchestra was headed by O. Chubynskyi, while Myroslav Turko temporarily became the director of the Drama section. In December 1942 the UAC appointed O. Chubynskyi the director of the section, whereas M. Prasitskyi became his assistant. At that time Yaroslav Andrukhovych, a well-known master of theatrical art, arrived in Peremyshl. He joined the section and became its art director and manager. By then, the material and financial position of the Drama section remained difficult. Its professional actors and orchestral players did not receive their salaries for two months. The debts for electricity, the rent of the hall, etc. accumulated. Eventually, the new management managed to solve all these problems. In January, 1943 for the first time the actors received their salary timely. Soon, the orchestra was reorganized and old promissory notes were paid. In fact, the section stepped on the way of the formation of a professional theatre [15, 7].

On March 2-3, 1943, in Lviv, a congress of representatives of the professional Ukrainian theatres took place, which was organized with the participations of the UCC. The administration members of the Drama section of the UAC in Peremyshl also took part in it. The congress made a decision to give a one-time sum of money of $15000 \mathrm{zl}$. to the section in Peremyshl and to appoint a constant help of $5000 \mathrm{zl}$. to it monthly. Right after the congress in Lviv the Drama section of the UAC in Peremyshl was reorganized into the "Ukrainian Theatre". The next month the UAC gave the theatre $20000 \mathrm{zl}$., of which $5000 \mathrm{zl}$. were used for work payment, and for the rest of the money suits, musical instruments, and materials for scenery were bought. Just then (in April, 1943) the Union of communities of Peremyshl region appropriated a one-time sum of $10000 \mathrm{zl}$. to the theatre, which, however, it could obtain only in October of this year [15, 7-7 rev.].

According to the UCC order, in July, 1943, the Theatre's Board of Commissars was formed, which included O. Chubynskyi and Y. Andrukhovych. It operated till August $15^{\text {th }}, 1943$, when the Board was headed by the Theatre's director Omelian Urbanskyi.

The results of the Ukrainian Theatre's artistic activity in the form of a theatre group and a section by the UAC (from March, 1942 to August, 1943) are presented in Table 1.

The Ukrainian Theatre's artistic activity in Peremyshl

Table 1. (from March, 1942 to August, 1943)

\begin{tabular}{|c|l|l|c|c|}
\hline № & \multicolumn{1}{|c|}{ The names of plays } & \multicolumn{1}{|c|}{ Producer } & $\begin{array}{l}\text { Performed in } \\
\text { Peremyshl }\end{array}$ & $\begin{array}{l}\text { Performed on } \\
\text { tour }\end{array}$ \\
\hline 1 & $\begin{array}{l}\text { "Poshylysia v durni" ("They were } \\
\text { made fools") }\end{array}$ & Y. Kostiuk & 3 times & - \\
\hline 2 & $\begin{array}{l}\text { "Char odnostroiu" ("The magic of } \\
\text { the uniform") }\end{array}$ & H. Zaslavets & 1 & 1 \\
\hline
\end{tabular}




\begin{tabular}{|c|c|c|c|c|}
\hline 3 & $\begin{array}{l}\text { "Zhyvi pokiinyky" ("The Live De- } \\
\text { ceased") }\end{array}$ & H. Zaslavets & 2 & - \\
\hline 4 & "Odruzhennia" ("Marriage") & Y. Kostiuk & 1 & - \\
\hline 5 & "Beztalanna" ("The unhappy") & V. Tsymbal & 3 & - \\
\hline 6 & $\begin{array}{l}\text { "Maty Naimychka" ("Mother the } \\
\text { Servant Woman") }\end{array}$ & H. Zaslavets & 4 & 4 \\
\hline 7 & $\begin{array}{l}\text { "Svatannia na Honcharivtsi" } \\
\text { ("Matchmaking at Honcharivka") }\end{array}$ & H. Zaslavets & 2 & 1 \\
\hline 8 & $\begin{array}{l}\text { "Espans'ka mukha" ("A Spanish } \\
\text { fly") }\end{array}$ & M. Prasitskyi & 3 & 3 \\
\hline 9 & $\begin{array}{l}\text { "Nich pid Ivana Kupala" ("The } \\
\text { night on the eve of the feast of } \\
\text { Ivan Kupalo") }\end{array}$ & H. Zaslavets & 2 & - \\
\hline 10 & $\begin{array}{l}\text { "loho velyke kokhannia" ("His } \\
\text { great love") }\end{array}$ & H. Zaslavets & 2 & 3 \\
\hline 11 & $\begin{array}{l}\text { "Chornomortsi" ("Black Sea } \\
\text { Cossacks") }\end{array}$ & V. Tsymbal & 2 & - \\
\hline 12 & "Skampolio" & Ya. Andrukhovych & 3 & - \\
\hline 13 & $\begin{array}{l}\text { "Mykolai dlia starykh" ("Santa } \\
\text { Claus for the old") }\end{array}$ & Ya. Andrukhovych & 1 & - \\
\hline 14 & $\begin{array}{l}\text { "Oi, ne khody, Hrytsiu" ("Hey, } \\
\text { Hryts, do not come to the party") }\end{array}$ & H. Zaslavets & 3 & 1 \\
\hline 15 & One-act performances & $\begin{array}{l}\text { Ya. Andrukhovych, } \\
\text { M. Prasitskyi }\end{array}$ & 2 & - \\
\hline 16 & "Taras Bulba" & Ya. Andrukhovych & 5 & - \\
\hline 17 & $\begin{array}{l}\text { "Shel'menko Chura" ("Servant } \\
\text { Shel'menko") }\end{array}$ & H. Zaslavets & 3 & 2 \\
\hline 18 & $\begin{array}{l}\text { "Pryvit vesni" ("A greeting to the } \\
\text { spring") }\end{array}$ & Ya. Andrukhovych & 3 & 2 \\
\hline 19 & A concert of the orchestra & O. Chubyns'kyi & 2 & - \\
\hline 20 & $\begin{array}{l}\text { "I u nas veselo" ("And we, too, } \\
\text { have fun") }\end{array}$ & Ya. Andrukhovych & 2 & - \\
\hline 21 & "Natalka Poltavka" & I. Bondarenko & 2 & 2 \\
\hline 22 & Asundryparty. part 1 & Ya. Andrukhovych & 1 & - \\
\hline 23 & Asundryparty. part 2 & E. Andrukhovych & 1 & - \\
\hline
\end{tabular}

The source: Central state archive of public associations of Ukraine (Kyiv). F. 166. D. 1. C. 115. S. 7 rev.

As is evident, Y. Andrukhovych, E. Andrukhovych, I. Bondarenko, and V. Tsymbal staged at that time. All 73 performances of the theatre were seen by 20245 spectators. The profit from the performances made up $107930.50 \mathrm{zl}$. The Theatre went on tour into such towns as Yaroslav, Dobromyl, Khyrov, Nyzhankovychi, and also performed in the villages of Dubetsko, Medyka, Korovychi, Orikhovets, Pykulych, Hnatkovychi, Bushkovychi, and Bolestrashych [15, 7 rev.].

In the new season (1943/1944) the Theatre was headed by O. Urbans'kyi, who defended the requirement of the transformation of the Theatre into an exclusively professional organization and, therefore, discharged semi-professional actors-amateurs. For that reason the theatre was not able to perform in the town for two months. Its several professional actors organized small tours in the villages of Peremyshl region, in which they showed two performances: "Mother the Servant Woman" and "Servant Shel'menko" [15, 7 rev.].

UCC became concerned with such a condition of the theatre. On October $27^{\text {th }}, 1943$ the sub-section of artistic affairs of the department of cultural work of the UCC cancelled an individual management of the Ukrainian Theatre in Peremyshl and created a Collective Board, consisting of director O. Chubynskyi, head of artistic affairs Ya. Andrukhovych, and head of administrative affairs O. Urbanskyi. For a reinforcement of theatre's company of actors the sub-section of art affairs of the UCC sent 32 persons to Peremyshl from the eastern regions of Ukraine, who were led by art director M. Mikhnovs'kyi. The new Board vigorously took to the opening of a new season and on November $7^{\text {th }}, 1943$ began it by a concert of the orchestra led by O.Chubyns'kyi and chorus under the direction of O. Ryzhkov. Soon, the staging of Goldani's comedy "Mirandolina", directed by V. Tsymbal, took place [15, 7 rev.-8].

However, in the end of November, 1943, by the order of the German power, the actors, who had arrived from the eastern areas had to leave the Theatre. Its activity again stopped. Then, the Theatre's Board 
again turned to the attraction of actors-amateurs, which produced certain results. In December, 1943 the Theatre staged "Santa Claus for children" directed by E. Andrukhovych, and in January of 1944 "The fairy tale of an old mill" and three shows, - "Let all come to theatre", "Laughter for all", and "You yourselves do not know what you have" (all directed by Y. Andrukhovych), were staged. Later the play "Give the heart a will" was staged (its director was $V$. Tsymbal) $[15,8]$.

In the beginning of February, 1944 director P. Borysovskyi arrived to Peremyshl, and in the middle of the same month Mykola Orel, the known actor, producer, and former director of Theatre "Prosvita" arrived there too. Already in the end of February the Theatre performed the play "A Servant Woman" (after T. Shevchenko's poem), and on March $11^{\text {th }}, 1944$ - on the occasion of the anniversary of Taras Shevchenko's birthday - play "Nazar Stodolia", was staged (both directed by P. Borysovskyi). At the anniversary performance on the occasion of the $80^{\text {th }}$ anniversary of the Ukrainian theatrical life in Galicia, the Theatre in Peremyshl prepared I. Tobilevych' comedy "The Chumaks", directed by M. Orel. In general, during the first half of 1943/1944 season the Ukrainian Theatre in Peremyshl performed 10 premieres, 14499 spectators saw its 42 performances. The profit of these performances made up $122059 \mathrm{zl}$. [15, 8].

On the whole, in February - March, 1944, the Ukrainian Theatre in Peremyshl consisted of 45 persons. The Collective Board consisted of Oleksander Chubynskyi, Yaroslav Andrukhovych, and Omelian Urbanskyi, the post of an artistic director was occupied by Mykola Orel, Petro Borysovskyí was its director. The troupe included 17 actors: Volodymyr Tsymbal, Alla Davydenko, Anna Kal'nytska, Vanda Korolevych, Lev Marko, Maria Marko, Liudmyla Ostroumova, Emma Sagulina, Serhiy Stel'mashchuk, Myroslav Turko, Yulia Urbans'ka, Roman Zelez, Myroslav Pavlyk, I. Fedchyshyn, Fedchyshyn (the first name is unknown), S.Pikhur, and Bohdan Kokh. The chorus consisted of seven persons: Zinaida Borysovs'ka, Antonina Dzalianska, N. Palamarchuk, Antonina Zadsianna, Vasyl Yavors'kyi, Ivan Volovchak, and Raisa Kravtsova. Also, seven musicians belonged to the orchestra: Volodymyr Bozheiko, Ivan Haba, Bronyslav Skoliarchik, Volodymyr Stan'ko, Olexander Snyshkevych, Kashchynets, and Kostyrko (to establish the first names of the last two persons was not possible). Besides, artistic painter Pavlo Koval' and a number of technical workers (stage workers, a cloakroom attendant, a joiner, etc.) also worked at the theatre [15, 5].

While characterising the Theatre's financial incomes from its artistic activity, it should be noticed that the Theatre received its greatest profits for its performances in April, July, and November of 1943 (2176, 3618, and $3469 \mathrm{zl}$. accordingly), and in January and February of 1944 (accordingly, 5152 and 3103 zl.). Usually, the income per performance made up from 120 to $500 \mathrm{zl}$. For example, "A greeting to the spring", performed on May $30^{\text {th }}, 1943$,brought the theatre $500 \mathrm{zl}$., "Mirandolina", on the $13^{\text {th }}$ and $14^{\text {th }}$ of November, 1943, yielded $450 \mathrm{zl}$., and show "Laughter for all", played on February $20^{\text {th }}, 1944$, gifted $450 \mathrm{zl}$. to the theatre. All these performances were shown in Peremyshl. During the tours the profits were lower. Thus, the performance of "Servant Shel'menko" on October $23^{\text {rd }}, 1943$ gave the theatre only $135 \mathrm{zl}$. [15, 3-4 rev.].

In February, 1944, - as the archival documents testify, - the Ukrainian Theatre in Peremyshl received a subvention (allegedly, from the UCC) of $15000 \mathrm{zl}$. In general, as compared with January, in February of 1944 its material-financial maintenance increased from 43776 to $91762 \mathrm{zl}$. Such a growth can be explained not only by profits from performances (as in February the profits from them were small), but also by the abovementioned subvention and a withdraw from the bank account of $22000 \mathrm{zl}$. It gave the chance to increase the salary to the workers of the theatre from 7311 to $13975 \mathrm{zl}$. and the bonuses from 7055 to $16026 \mathrm{zl}$. Some money was spent for the purchase of tools and scenery means, which total cost grew from 12803 to $15443 \mathrm{zl}$. Certainly, the taxes paid by the theatre increased as well, - from 2799 to $5870 \mathrm{zl}$. [15, $6]$.

Unfortunately, for the lack of historical sources, the further destiny of the Ukrainian Theatre in Peremyshl is not known. Still, on March $10^{\text {th }}, 1944$ O. Urbans'kyi, the director of the Ukrainian Theatre in Peremyshl, sent a request to the cultural work department (to the sub-section on artistic affairs) of the UCC, which was in Lviv, to award the musical art director O. Chubynskyi, member of the Board Y. Andrukhovych (as an actor), art director Mykola Orel, artistic painter Pavlo Koval, and actor Volodymyr Tsymbal [15, 13]. However, it is not known, whether or not this request was satisfied. The Eastern front was gradually approaching Peremyshl, so, the evacuation of authorities, economic organizations, public societies, and cultural establishments began in the spring and summer of 1944 . As M. Prasitskyi remembered, on July $24^{\text {th }}, 1944$ "a considerable number of Ukrainian public figures, by force of the circumstances menacing from the Bolshevism had to leave their native land and the majority of the Ukrainian Theatre's actors did that" [13, 338]. On July $27^{\text {th }}, 1944$ the Soviet army again occupied the town $[16,87]$. The war put an end to the activity of the Ukrainian Theatre in Peremyshl, but its separate workers still continued their work at a professional Theatre which operated in "The People's House" until May, 1945 on a co-operative society bases. Its directors were Serhiy Stelmashchuk and Mykola Orel, Ivan Baran was the manager, Bohdan Kokh was ballet master, and V. Romanyk was the head of its chorus [11, 307]. In 1945 - 1946 almost all the Ukrainian population of Peremyshl was taken out to the Ukr. SSR, the actors of the former Ukrainian Theatre among them.

The conclusions. So, the historical origin of the Ukrainian Theatre in Peremyshl, which operated in the days of the Nazi occupation, was connected with the activity of "Lesia Ukrainka theatrical society" in it (1925 - 1939) and the Soviet State Ukrainian regional drama theatre $(1940-1941)$. The history of the Ukrainian Theatre in Peremyshl $(1942-1944)$ can be divided into three stages: 1$)$ the stage of its formation 
in the form of a Theatre group and a Drama sub-section of the UAC (1942 in first half of 1943), 2) the stage of a reorganization of Theatre into a professional establishment (August - October, 1943), 3) the stage of its active artistic activity on professional bases (November, 1943 - July, 1944). The art reserve of the Ukrainian Theatre has affected several dozens of premieres and almost one hundred performances in Peremyshl and the neighbouring towns and villages. Its creativity was expressively characterised by Ukrainian motives and by staging of classical Ukrainian and foreign dramatic compositions.

\section{Notes}

1 Публікація містить результати досліджень, проведених у рамках виконання наукового проекту «Українсько-польськоєврейські взаємини у Східній Галичині (перша половина XXст.): історичний досвід, уроки для сучасності», що фінансується за рахунок коштів загального фонду державного бюджету. ID:95861 29.08.2017 (176-1).

\section{תimepamypa}

1. Антополь Г., Хільченко А. Молодь обласного театру // Більшовицька правда. 1940. № 260 (6 листопада). С. 2.

2. Брусиловський І. Актриса Ольга Шибко (кандидат в депутати Перемишльської міської ради) // Більшовицька правда. 1940. № 286 (10 грудня). С. 2.

3. Ванюга Л. С. Діяльність Українського драматичного театру ім. Івана Франка в Тернополі: період німецької окупації // Вісник Державної академії керівних кадрів культури і мистецтв : науковий журнал. 2012. № 4. С. 121-126.

4. Гайдабура В. М. Театр, захований в архівах. Сценічне мистецтво в Україні періоду німецько-фрашистської окупації (1941 - 1944). К.: Мистецтво, 1998. 220 с.

5. Гайдабура В. М. Театр між Гітлером і Сталіним: Україна. 1941 - 1944. Долі митців. К.: Факт, 2004. 320 с.

6. Демідко О. Театральна культура Маріуполя у період німецької окупації (1941 - 1943) // Східноєвропейський історичний вісник. 2018. Вип. 6. С. 156-162.

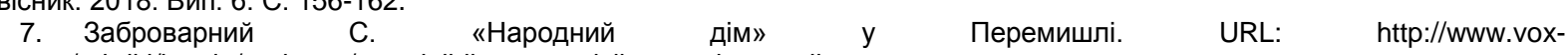
populi.com.ua/rubriki/istoria/nadsann/narodnijdimuperemisliavtorzabrovarnijstepan

8. Кулик А. У звільненому Стрию // Більшовицька правда. 1939. № 42 (26 грудня). С. 2.

9. Культурне життя в Україні. Західні землі: Документи і матеріали. Т. 1 (1939 - 1953). К.: Наук. думка, 1995.748 с.

10. Паньківський К. Роки німецької окупації. Нью-Йорк - Торонто: Життя і мислі, 1965. 480 с.

11. Пилип-Андрушків М. Український театр у Перемишлі 1941 - 1944 рр. // Перемишль і Перемиська земля протягом віків / Наукове товариство ім. Шевченка у Польщі; під ред. С. Заброварного. Перемишль - Львів. С. 306-308.

12. Попович О. Українське музичне життя Перемишля $(1919$ - 1999). Авторефрерат ... канд. мистецтвознавства. Київ: Інститут мистецтвознавства, фольклористики та етнології ім. М. Т. Рильського НАН України, 2003. 17 с.

13. Прасіцький М. “Драматичне товариство ім. Лесі Українки” в Перемишлі // Перемишль. Західний бастіон України: Збірник матеріалів до історії Перемишля і Перемиської землі зладжений редакційною колегією під проводом проф. Б. Загайкевича. Нью-Йорк; Філадельфія, 1961. С. 335-339.

14. Урбанський О. Театральні мандри / Омелян Урбанський // Наш театр. Книга діячів українського театрального мистецтва. - Нью-Йорк; Париж; Сідней; Торонто. 1975. Т. 1. С. 803-816.

15. Центральний державний архів громадських об’єднань України (м. Київ). Ф. 166. Оп. 1. Спр. 115. 13 арк.

16. Шах С. Де срібнолентий Сян пливе. Історичний нарис державної української гімназії в Перемишлі. Брюссель: Накл. То-ва «Рідна школа», 1977. 146 с.

\section{References}

1. Anatol, H., \& Khilchenko, A. (1940). The youth of the regional theatre. Bilshovytska Pravda, 260, 2 [in Ukrainian].

2. Brusylovs'kyi I. (1940). The actress Olha Shybko (the depute candidate of Peremyshl town council). Bilshovytska Pravda, 286, 2 [in Ukrainian].

3. Waniuga, L. S. (2012). The activity of the Ivan Franko Ukrainian Drama Theatre in in Ternopil: the German occupation period. State Academy of Managerial Staff of Culture and Arts Herald, 4, 121-126 [in Ukrainian].

4. Haidabura, V. M. (1998). A theatre hidden in the archives. Scenic art in Ukraine in the period of the occupation of the fascist Germany (1941 - 1944). Kyiv: Mystetstvo [in Ukrainian].

5. Haidabura, V. M. (2004). The theatre between Hitler and Stalin: Ukraine in $1941-1944$. The fates of the artists. Kyiv: Fakt [in Ukrainian].

6. Demidko, O. (2018). The theatrical culture of Mariupil in the period of the Nazi occupation (1941 - 1943). East European Historical Bulletin, 6, 156-162 [in Ukrainian].

7. Zabrovarnyi, S. (2012). "The People's House" in Peremyshl. URL: http://www.voxpopuli.com.ua/rubriki/istoria/nadsann/narodnijdimuperemisliavtorzabrovarnijstepan [in Ukrainian].

8. Kulyk, A. (1939). In the liberated Stryi. Bilshovytska Pravda, 42, 2 [in Ukrainian].

9. Slyvka, Y. (Eds.). (1995). Cultural life in Ukraine. Its Western Lands: documents and materials. Vol. 1 (1939 - 1953). Kyiv: Naukova dumka [in Ukrainian].

10. Pan'kivskyi, K. (1965). The years of the German occupation. New-York - Toronto: Life and Thoughts [in Ukrainian].

11. Pylyp-Andrushkiv, M. (1996). Ukrainian Theatre in Peremyshl in 1941 - 1944. S. Zabrovarnyi (Eds.), Peremyshl and Peremyshl land during centurie (pp. 306-308). Peremyshl -Lviv [in Ukrainian].

12. Popovych, O. (2003). Ukrainian musical life of Peremyshl (1919-1999). Extended abstract of candidate's thesis. Kyiv: M. T. Ryls'kyi Institute of Art Study, Folklore Study, and Ethnology of the NAS of Ukraine [in Ukrainian].

13. Prasitskyi, M. (1961). "Lesia Ukrainka theatrical society" in Peremyshl. B. Zahaikevych (Eds.), Peremyshl, Ukraine's western bastion: a collection of materials on the history of Peremyshl and Peremyshl land (pp. 335-339). New-York, Philadelphia [in Ukrainian].

14. Urbanskyi, O. (1975). Theater tours. H. Luzhnytskyi (Eds.), Our Theater. Book of the leaders of Ukrainian theatrical art. (Vol. 1), (pp. 803-816). New York; Paris; Sydney; Toronto [in Ukrainian].

15. Central state archive of public associations of Ukraine (Kyiv). F. 166. D. 1. C. 115. 13 p. [in Ukrainian].

16. Shakh, S. (1977) Where the silver-stripped Sian flows. A historical sketch of the Ukrainian State Gymnasium in Peremyshl. Brussels: Ridna shkola society [in Ukrainian]. 